\title{
SPRING TRITICALE TECHNOLOGY DEPENDING ON CROP ROTATION
}

\author{
Boguslawa Jaskiewicz \\ Institute of Soil Science and Plant Cultivation State Research Institute in Pulawy, Poland \\ kos@iung.pulawy.pl
}

\begin{abstract}
The aim of the study was to determine the influence of production technology intensity on the yield level of spring triticale cultivars Nagano and Legalo, depending on the percentage of cereals in the sowing structure (50, 75, $100 \%$ ). In 2012 and 2016 a field experiment was conducted in ES IUNG - PIB in Pulawy, Poland, on the soil of a good wheat complex. The research factors were intensive and integrated production technologies, and Nagano and Legalo cultivars. the yields of spring triticale grains depended mainly on hydrothermal conditions in the years of research, production technology, and genetic factor. In 2012, under conditions of $100 \%$ share of cereals in crop rotation and intensive technology, grain yields were by 0.76 t.ha $^{-1}$ higher than those obtained under the integrated technology. Lower precipitation in June (2016) compared to the long-term average, resulted in similar yields of triticale under both production technologies. In the rotation with a lower percentage of cereals, a higher triticale grain yield was obtained than in cereal monoculture. The evaluation of the applied production technologies showed that Nagano cultivar yielded higher than other tested cultivars.
\end{abstract}

Keywords: technology, spring triticale, yielding, crop rotation.

\section{Introduction}

In Poland, spring triticale accounts for $3 \%$ of the grain sowing structure. It has lower soil requirements than wheat and spring barley [1;2]. Triticale is harvested mainly for fodder because it is characterized by high nutritional value of grains [3]. It contains less fibre than barley or oat grain and is richer in protein, which is distinguished by a good amino acid composition and a high digestibility factor $[4 ; 5]$. Many studies $[3 ; 4 ; 6-10]$ show that there are great possibilities of shaping the yield of cereals through an appropriate selection of agrotechnical treatments, including plant protection treatments and nitrogen fertilization.

In spring triticale cultivation, it is important to determine the optimum intensity of production technology adapted to local soil and climate conditions [11;12].

Increasing the intensity of production adversely affects the natural environment. An alternative to the intensive system is integrated technology. In integrated production, the use of chemical plant protection products is limited to the necessary minimum, and the rates of mineral fertilizers are determined on the basis of the abundance of soil in nutrients and the assessment of the level of plant nutrition $[12 ; 13]$.

In recent years, the percentage of cereals in the sowing structure has been increasing. One way to counteract the decline in cereal yields is to use a cultivation technology that provides plants with optimal conditions for growth and development.

It is assumed that spring triticale cultivars, under conditions of increasing percentage of cereals in the sowing structure, will respond in a different way to production technologies.

The aim of this study was to determine the impact of production intensity on the yield of spring triticale cultivars, depending on the percentage of cereals in the sowing structure.

\section{Materials and methods}

The research was conducted in 2012 and 2016 in ES IUNG -PIB in Osiny $\left(51^{\circ} 15^{\prime} \mathrm{N}, 22^{\circ} 18^{\prime} \mathrm{E}\right)$. The two-factor split plot experiment was carried out on plots measuring $49 \mathrm{~m}^{2}$ in 3 replications. Spring triticale was sown in the first decade of April. The experiment was conducted simultaneously in three fields, with $50 \%, 75 \%$ and $100 \%$ share of cereals in the sowing structure. The first experimental factor was the production technology (integrated and intensive) and the second one - spring triticale cultivars (Legalo and Nagano). The applied technologies differed in terms of the level of mineral fertilization and chemical plant protection against pathogens (Table 1). In the integrated production technology, chemical spraying was applied after exceeding the harmfulness threshold [14]. In the full maturity stage, spring triticale grain yield was determined. 
The obtained results were statistically worked out in the Statistica program, using the ANOWA variance analysis method, and the differences were estimated using the Tukey's test at the level of significance $p=0.05$.

Weather conditions in 2012 and 2016 favorably influenced the emergence and tillering of spring triticale plants. In both growing seasons, air temperature was similar to the long term average. Particularly high precipitation deficits were recorded in May 2012 during the shoot formation period and in June 2016 during the earring period. On the other hand, precipitation above the long term average, which positively affected the formation of shoots on the plant. July 2012 was exceptionally wet, was recorded in May 2016.

Table 1

Seed, fertilizers and number of pesticide treatments used in technologies

\begin{tabular}{|l|c|c|c|c|c|c|c|c|c|}
\hline \multirow{2}{*}{ Technology } & Seeds material $\left(\mathrm{kg}^{-1} \mathbf{h a}^{-1}\right)$ & \multicolumn{9}{c|}{ Fertilisers } & \multicolumn{3}{c|}{ Number of treatments } \\
\cline { 2 - 10 } & Legalo & Nagano & $\mathbf{N}$ & $\mathbf{P}_{\mathbf{2}} \mathbf{0}_{\mathbf{5}}$ & $\mathbf{K}_{\mathbf{2}} \mathbf{0}$ & $\mathbf{H}^{\prime \mathbf{1}}$ & $\mathbf{F}$ & $\mathbf{I}$ & $\mathbf{R}$ \\
\hline \multicolumn{8}{|c|}{ Year of harvest 2012 } \\
\hline Integrated & 220 & 206 & 62 & 66 & 82 & 2 & 1 & 1 & 1 \\
\hline Intensive & 200 & 191 & 84 & 78 & 94 & 2 & 2 & 1 & 1 \\
\hline \multicolumn{8}{|c|}{ Year of harvest 2016 } \\
\hline Integrated & 220 & 206 & 66 & 68 & 81 & 1 & 1 & 1 & 1 \\
\hline Intensive & 200 & 191 & 88 & 82 & 93 & 2 & 3 & 1 & 1 \\
\hline
\end{tabular}

${ }^{\pi 1} \mathrm{H}$ - Herbicides, F - Fungicides, I - Insecticides, R - Retardants

Weather conditions in the period from March to July in 2012 and 2016

Table 2

\begin{tabular}{|c|c|c|l|}
\hline Months & $\mathbf{2 0 1 2}$ & $\mathbf{2 0 1 6}$ & Multiplicity (1871-2008) \\
\hline \multicolumn{4}{|c|}{ Temperature $\left.\mathbf{(}^{\mathbf{}} \mathbf{C}\right)$} \\
\hline March & 4.9 & 4.3 & 1.6 \\
\hline April & 9.9 & 9.6 & 7.8 \\
\hline May & 15.7 & 15.6 & 13.5 \\
\hline June & 17.7 & 19.8 & 16.8 \\
\hline July & 21.4 & 20.1 & 18.5 \\
\hline \multicolumn{5}{|c|}{ Rainfalls (mm) } \\
\hline March & 20.3 & 53 & 30 \\
\hline April & 34.1 & 38.4 & 40 \\
\hline May & 35.8 & 72.2 & 57 \\
\hline June & 72.9 & 27.9 & 70 \\
\hline July & 113 & 86.6 & 84 \\
\hline
\end{tabular}

\section{Results and discussion}

The grain yield of spring triticale depended on hydrothermal conditions in the years of research, production technology, and genetic factor (Fig. 1, 2, 3). Interactions among the studied factors occurred at 50, 75 and $100 \%$ share of cereals in crop rotations (Fig. 2, 3).

The yield level of spring triticale was influenced by the course of weather conditions in the growing season. Cereals exhibit sensitivity to periodic water shortages and respond with variable grain yield [8;10]. Favorable weather conditions in 2012 in the period of shoot formation and grain formation, had a positive effect on winter triticale grain yields. They were higher by $6 \%$ compared to 2016 under conditions of 50, 75 and $100 \%$ share of cereals in the sowing structure (Fig. 1). The intensive production technology contributed to an increase in spring triticale yields. Nagano cultivar was characterized by significantly higher grain yields compared to Legalo cultivar (Fig. 1). The grain yield of winter triticale of Nagano cultivar increased by $4-5 \%$ under $50 \%$ and $100 \%$ share of cereals in the sowing structure, and by $10 \%$ at $75 \%$ share of cereals in the sowing structure.

Higher spring triticale yields were obtained under the conditions of $50 \%$ share of cereals in the sowing structure, while lower in cereal monoculture (Fig. 1). According to Smagacz and Kuś [15], 
relatively high cereal grain yields can be obtained in cereal crop rotations, however, in each case, lower than under $50 \%$ share of cereals in the sowing structure.

For each variant of cereal percentage $(50 \%, 75 \%$ and $100 \%)$, interaction was found in the level of spring triticale yields between years and production technologies (Fig. 2), as well as production technologies and cultivars (Fig. 3).

Under conditions of $50 \%$ share of cereals in the sowing structure in 2012, the spring triticale grain yield under the intensive production technology was higher by $21 \%$ compared to the integrated technology and from $11 \%$ to $20 \%$ for both production technologies in 2016 (Fig. 2). Given the higher amount of precipitation in June 2012, compared to the long term average, plants had better conditions for growth and development under the intensive technology than under the integrated technology. On the other hand, under conditions of a lower amount of precipitation in relation to the long term average, i.e. in 2016, a lower level of spring triticale yields under both production technologies, was achieved. On average, the spring triticale grain yield in 2016 was lower by $0.4 \mathrm{tha}^{-1}$ compared to the yield in 2012. On the other hand, the average triticale grain yield from the integrated technology was lower by 0.16 tha $^{-1}$ in relation to the intensive technology. Yield and quality of triticale grains are largely determined by agrotechnical factors, among which mineral fertilization, especially nitrogen [16], has a large impact.

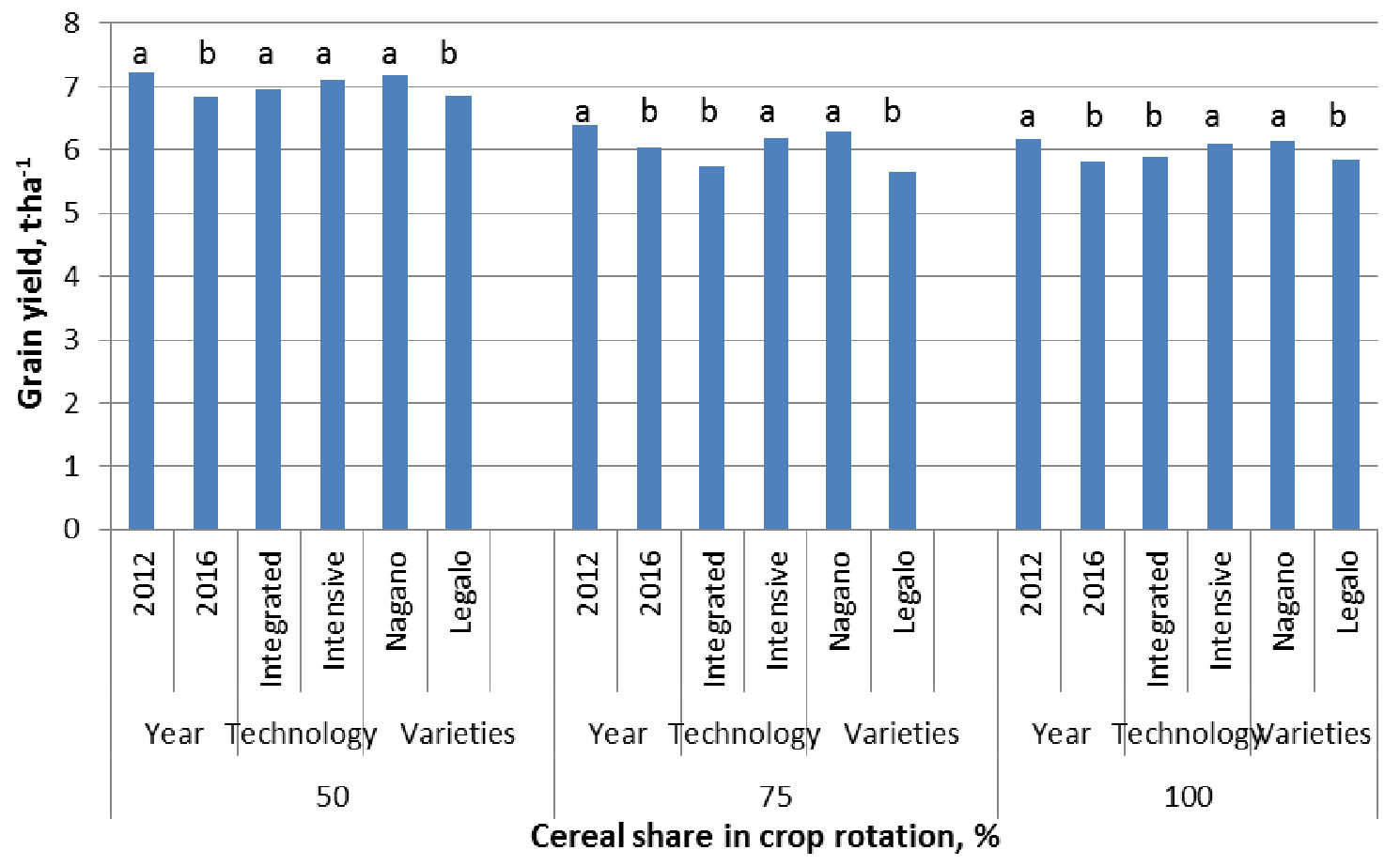

Fig. 1. Triticale yields $\left(t^{-1} a^{-1}\right)$ for the year of harvest, technology, genetic factor and crop rotation: $a, b$-different letters denote statistically significant differences $(\alpha=0.05)$

Under $50 \%$ and $75 \%$ share of cereals in the sowing structure, the level of spring triticale yields from the integrated technology was similar in both years of research (Fig. 2). On the other hand, in 2012 spring triticale from the intensive technology, as compared to the integrated technology, achieved yields higher by 9-11\%. Under conditions of cereal monoculture and intensive production technology in 2012, grain yields were by 0.76 tha $^{-1}$ higher than in the integrated technology (Fig. 2). In 2016, the level of triticale yields in intensive technology was similar to that of the integrated technology in 2012. On the other hand, the integrated production technology yields of grain were by $6 \%$ higher than those under the same technology in 2016. Triticale grain yields depended to a large extent on weather conditions in the growing season. In 2012, the amount of rainfall satisfied the needs of plants, providing favorable conditions for the growth and development of triticale.

The average triticale yield in monoculture conditions in 2012 was higher by $9 \%$, i.e. by $0.56 \mathrm{t} \cdot \mathrm{ha}^{-1}$ as compared to 2016. In the three-year study, Nierobca et al. [17], winter triticale of Kitaro 
cultivar under cereal monoculture yielded best after the application of intensive and medium-intensive technology, while the lowest, under the economical technology. In the Klimota study [6], triticale protected with herbicide significantly increased the number of ears per unit of area each year, yielding at the level of $5.26 \mathrm{t} \cdot \mathrm{ha}^{-1}$ with a control yield amounting to $4.66 \mathrm{t} \cdot \mathrm{ha}^{-1}$. The impact of weather conditions, cultivation intensity, and cultivar was also observed in the Kołodziejczyk and Szmigla [7] studies on spring wheat. The average grain yield of the evaluated spring wheat cultivars, grown according to the intensive technology was $7.11 \mathrm{t} \cdot \mathrm{ha}^{-1}$, being by $26.5 \%$ higher than the yield obtained in medium-intensive cultivation.

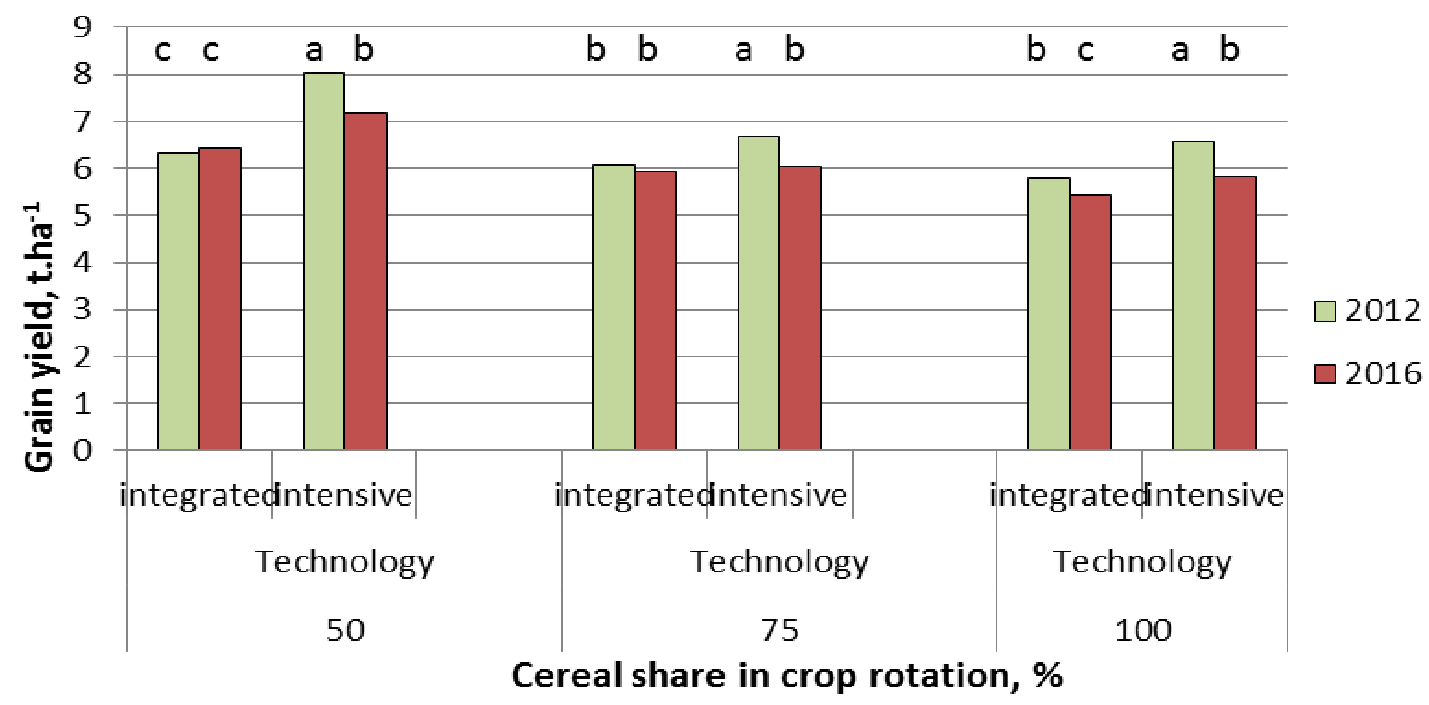

Fig. 2. Spring triticale grain yield depending on the year of harvesting and cultivation technology with at 50,75 and $100 \%$ cereals in crop rotation: $a, b, c-$ different letters denote statistically significant differences $(\alpha=0.05)$

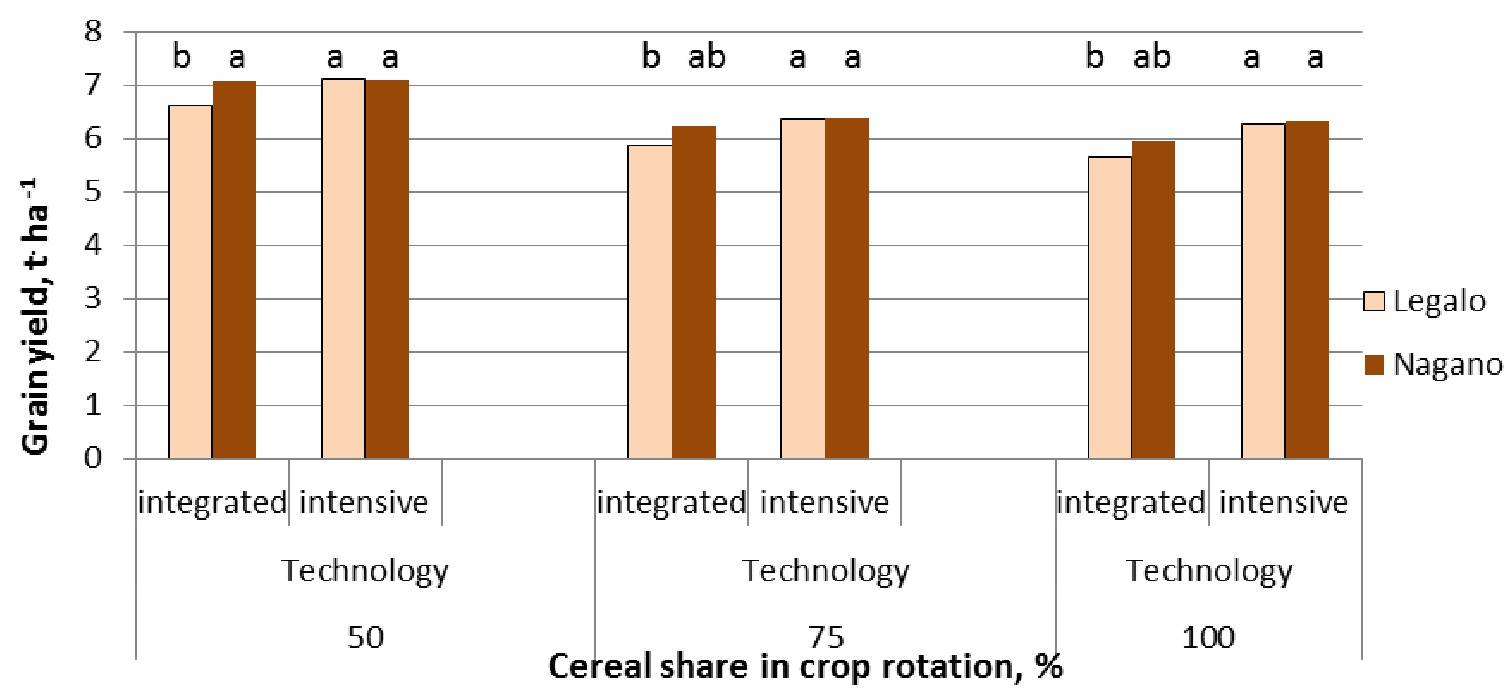

Fig. 3. Grain yield of spring triticale varieties, depending on the cultivation technology with at 50, 75 and $100 \%$ cereals in crop rotation: $a, b$ - different letters denote statistically significant differences $(\alpha=0.05)$.

After applying the intensive production technology, both spring triticale cultivars yielded significantly higher. On the other hand, the grain yield of the studied cultivars was differentiated by the integrated technology. Under conditions of $50 \%$ share of cereals in the sowing structure and intensive production technology, the tested cultivars yielded at the same level, similarly to Nagano cultivar yields obtained from the integrated production technology. In the integrated production 
technology, cultivar Legalo produced $0.3 \mathrm{tha}^{-1}$ lower grain yield than in the intensive technology. A higher level of triticale yield in intensive production conditions was obtained by Mut et al. [9]. Under conditions of $75 \%$ share of cereals in the sowing structure and in cereal monoculture, grain yield of Lagalo cultivar under the integrated technology was lower than under the intensive technology (Fig. 3). The level of Nagano cultivar yields in the integrated technology was at the level of spring triticale grain yield from the intensive technology and Legalo cultivar from the integrated technology. Klikocka et al. [18] explained this by the differentiated needs of the genotype, which changes yield components under conditions of limited plant access to light, resulting from the increase in the density of ears per unit area.

\section{Conclusions}

1. The grain yield of spring triticale depended mainly on hydrothermal conditions in the period of research, genetic factor, and production intensity.

2. In 2012, under conditions of a lower percentage of cereals in crop rotations, spring triticale grain yield in intensive production technology was by $21 \%$ higher compared to the integrated technology, and 11-20\% higher than in both technologies in 2016.

3. Under conditions of $100 \%$ share of cereals in rotation and intensive production technology in 2012 , grain yields were by 0.76 t.ha $^{-1}$ higher than in the integrated technology.

4. Lower amounts of precipitation in June (2016) compared to the long term average, resulted in similar yields of triticale under both production technologies.

5. In the correct crop rotation, a higher yield of triticale grain was obtained than under cereal monoculture. In the evaluation of the applied production technologies, Nagano cultivar yielded higher than other cultivars.

\section{References}

[1] Jaśkiewicz B. Uprawa pszenżyta jarego (Spring triticale cultivation). Instrukcja upowszechnieniowa. IUNG-PIB Puławy, 182, 2011, pp. 1-35. (In Polish).

[2] Roques S.E., Kindred D.R., Clarke S. Triticale out-performs wheat on range of UK soil with a simi-lar nitrogen requirement. Journal of Agricultural Science 155, 2017, pp. 261-281.

[3] Jaśkiewicz B., Szczepanek M. Crop management and variety have influence on alkylresolcinol content in triticale grain. Acta Agriculturae Scandinavica, Section B- Soil Plant Science, vol. 66 (7), 2016, pp. 570-574. doi.org/10.1080/09064710.2016.1201139

[4] Jaśkiewicz B. Szczepanek M. Amino acids content in Triticale grain depending on meteorological, agrotechnical and genetic factors. Latvia University of Life Sciences and Technologies, Proceedings of 24th International Scientific Conference, Jelgava, vol. 2, 2018, pp. 28-35. Available at: http://www2.1lu.lv/research_conf/proceedings.htm

[5] Tohver M., Kann A., Taht R., Mihhalevski A., Hakman J. Quality of triticale cultivars suitable for growing and bread-making in northern conditions. Food Chemistry, 89, 2005, pp. 125-132.

[6] Klimont K. 2007. Wpływ herbicydów na plon ziarna i strukturę plonu zbóż (Impact of herbicides on grain yield and grain yield structure). Biuletyn IHAR, 243, 2007, pp. 69-81 (In Polish).

[7] Kołodziejczyk M., Szmigiel A. Wpływ intensywności technologii uprawy na plonowanie wybranych odmian pszenicy jarej (Influence of tillage technology intensity on yields of selected spring wheat cultivars). Fragmenta Agronimica, 31 (3), 2014, pp. 75-84. (In Polish)

[8] Kwiecińska-Poppe E., Kraska P., Andruszczak S., Pałys E. Plon oraz wybrane cechy jakości ziarna pszenżyta ozimego uprawianego $w$ monokulturze $w$ warunkach stosowania zróżnicowanych dawek herbicydów oraz nawożenia dolistnego (Yield and selected quality traits of winter triticale grains grown in monoculture under the application of differentiated herbicide rates and foliar fertilizer). Progres in Plant Proection, 50, 2010, pp. 999-1003. (In Polish)

[9] Mut Z., Sezer I., Gulumser A. Effect of different sowing rates and nitrogen levels on grain yield, yield components and some quality traits of triticale. Asian Journal of Plant Science 4, 2005, pp. 533-539.

[10] Woźniak A. Plonowanie pszenżyta jarego w różnych systemach następstwa roślin. Biuletyn IHAR. 223/224, 2002, pp. 159-168. (In Polish) 
[11] Holland J. The environmental consequences of adopting conservation tillage in Europe: reviewing the evidence. Agriculture, Ecosystems \& Environment 103, 2004, pp. 1-25.

[12] Kumhalova J., Matejkova S., Fifernova M., Lipavski J., Kumhala E. Topography impact on nutrition content in soil and yield. Plant, Soil and Environment 54, 2008, pp. 255-261.

[13] Korbas M., Mrówczyński M. Metodyka integrowanej ochrony pszenżyta ozimego i jarego (Methodology of integrated protection of winter and spring triticale). Wydawnictwo IOR_PIB, Poznań, 2011, pp. 1-189. (In Polish)

[14] Koziara W. Wzrost, rozwój oraz plonowanie pszenżyta jarego i ozimego w zależności od czynników meteorologicznych i agrotechnicznych (Growth, development, and yields of spring and winter triticale depending on meteorological and agrotechnical factors). Roczniki AR Poznań 269, 1996, pp. 1-101. (In Polish)

[15] Smagacz J., Kuś J. Wpływ długotrwałego stosowania płodozmianów zbożowych na plonowanie zbóż oraz wybrane chemiczne właściwości gleby (The influence of long-term crop rotation on cereal yields and selected chemical properties of the soil). Fragmenta Agronomica, 27(4), 2010, 119-134. (In Polish)

[16] Weber R., Hryńczuk B. 2007. Plon i komponenty plonu pszenżyta w zależności od sposobu uprawy roli po wieloletnim odłogu (Yield and components of triticale yield depending on the method of tillage after many years of fallow). Fragmenta Agronomica, 2(94), 2007, pp. 381-389. (In Polish)

[17] Nieróbca P., Grabiński J., Szeleźniak E. 2008. Wpływ intensywności technologii uprawy w płodozmianie zbożowym na efektywność produkcyjną i ekonomiczną (Impact of the intensity of crop rotation technology on production and economic efficiency). Acta Scientiarum Polonorum, Agricultura, 7(3), 2008, pp. 73-80. (In Polish)

[18] Klikocka H., Juszczak D., Głowacka A. Wpływ uprawy roli i nawożenia siarką na komponenty plonu pszenżyta jarego (The impact of tillage and sulphur fertilization on spring triticale yield components). Fragmenta Agronomica. 3(4), 2014, pp. 47-57. (In Polish) 